\title{
Article \\ The Content of Polycyclic Aromatic Hydrocarbons in Slavonska slanina-Traditionally Smoked and Dry-Cured Bacon
}

\author{
Brankica Kartalović ${ }^{1}$ D, Leona Puljić ${ }^{2}$, Dragan Kovačević ${ }^{3}$, Mateo Markovčić ${ }^{3}$, Jelena Vranešević ${ }^{1}$, \\ Kristina Habschied ${ }^{3, *}$ (D) and Krešimir Mastanjević ${ }^{3, * \text { (D) }}$ \\ 1 Scientific Veterinary Institute Novi Sad, Rumenački put 20, 21000 Novi Sad, Serbia; \\ brankica@niv.ns.ac.rs (B.K.); jelenababic@niv.ns.ac.rs (J.V.) \\ 2 Faculty of Agriculture and Food Technology (APTF), University of Mostar, Biskupa Čule bb, \\ 88000 Mostar, Bosnia and Herzegovina; leonapuljic224@gmail.com \\ 3 Faculty of Food Technology Osijek, Josip Juraj Strossmayer University of Osijek, F. Kuhača 20, \\ 31000 Osijek, Croatia; dragan.kovacevic@ptfos.hr (D.K.); mmarkovcic@ptfos.hr (M.M.) \\ * Correspondence: kristinahabschied@gmail.com (K.H.); kmastanj@gmail.com (K.M.); \\ Tel.: +385-31-224-300 (K.M.)
}

check for

updates

Citation: Kartalović, B.; Puljić, L.;

Kovačević, D.; Markovčić, M.;

Vranešević, J.; Habschied, K.;

Mastanjević, K. The Content of

Polycyclic Aromatic Hydrocarbons in

Slavonska slanina-Traditionally

Smoked and Dry-Cured Bacon.

Processes 2022, 10, 268. https://

doi.org/10.3390/pr10020268

Academic Editors: Chi-Fai Chau and Carl Schaschke

Received: 15 December 2021

Accepted: 27 January 2022

Published: 29 January 2022

Publisher's Note: MDPI stays neutral with regard to jurisdictional claims in published maps and institutional affiliations.

Copyright: (C) 2022 by the authors. Licensee MDPI, Basel, Switzerland. This article is an open access article distributed under the terms and conditions of the Creative Commons Attribution (CC BY) license (https:// creativecommons.org/licenses/by/ $4.0 /)$
Abstract: The goal of this study was to determine the concentrations of 16 PAHs (PAH16) naphthalene-Nap, acenaphthylene-Anl, acenaphthene-Ane, fluorene-Flu, phenanthrene-Phen, anthracene-Ant, fluoranthene-Flt, pyrene-Pyr, benz[a]anthracene-BaA, chrysene-Chry, benzo[b]fluoranthene- $\mathrm{BbF}$, benzo[k]fluoranthene-BkF, benzo[a]pyrene- $\mathrm{BaP}$, indeno[1,2,3-cd]pyreneInP, dibenz[a,h]anthracene-DahA and benzo[g,h,i]perylene-BghiP) in Slavonska slanina traditionally smoked bacon over open fire and industrially smoked on a smoke generator with a heated plate. In the samples of Slavoska slanina smoked in a traditional manner, the presence of 11 out of 16 analyzed PAHs was determined (Nap, Anl, Ane, Fln, Ant, Phen, Flt, BaA, Pyr, BbF, BkF). In the samples smoked in industrial conditions, only 2 out of 16 (Nap, Anl) were quantified. In the samples smoked with open fire (the traditional method), PAH4 (BaA, BaP BbF, Chry) concentations were as follows: $14.84 \mathrm{\mu g} \mathrm{kg}^{-1}$ in the middle, $10.60 \mu \mathrm{g} \mathrm{kg}^{-1}$ on the surface and $17.37 \mu \mathrm{g} \mathrm{kg}^{-1}$ in the skin, while the PAH4 content in the samples smoked in industrial conditions were below the level of quantification $(<\mathrm{LOQ})$. The content of carcinogenic $\mathrm{BaP}$ was below the limit of quantification in all investigated samples. These findings support the fact that traditional smoking may result in a product safe for consumption, as far as the prescribed legislative recommendations are concerned, but constant monitoring is still needed.

Keywords: Slavonska slanina; smoked dry bacon; PAH; traditional and industrial smoking

\section{Introduction}

Traditional dry-cured and smoked bacon (Slavonska slanina) is a traditional Croatian product originally produced in the Eastern region of Croatia called Slavonija. The main difference between this bacon and other Croatian and European bacons is the application of cold smoke in the production process and no seasoning (like adding pepper and aromatic herbs) during salting. The product is rectangular in shape and is made from pork belly with fat and muscle tissue and skin. It is produced using multiple processes, such as salting without the addition of spices followed by cold smoking, and lastly drying and ripening procedures [1].

Compared to hams (or prosciutto) whose technological production process lasts for at least 12 months [2], the bacon production process is significantly shorter and lasts about 45 days. Due to the shorter production process, and especially the shorter ripening phase, the final product has a weaker aromatic profile compared to prosciutto.

Meat smoking is one of the oldest methods of the conservation of fresh meat and meat products. It is defined as a process of adsorption of volatiles originating from burning wood [3]. In recent years, there has been an increase in the consumption of traditional meat 
products such as sausage, ham and bacon. People recognize the quality and efforts of small, local producers who strive to achieve the highest possible level of quality in their products. In addition, Croatian and European labels of origin for agricultural and food products such as protected designations of origin and protected geographical indications contribute to consumer confidence in those products [4].

Smoking has a triple effect on meat products: positive effects such as changes in sensory properties (smell and taste) and nutritional quality of meat products and preservative effect [5]. However, it also has some negative side effects such as absorption of polycyclic aromatic hydrocarbon (PAH) compounds [6-9].

Currently, a great emphasis is placed on the study of aromatic hydrocarbons with multiple nuclei, i.e., PAHs that are formed during combustion. Many of these compounds are carcinogenic, and compounds such as pyrene and benzo[a] pyrene are present in cigarette smoke, but also in traditionally smoked meat products (sausages, hams and prosciuttos) [10-15]. Polycyclic aromatic hydrocarbons are a widely spread group of organic molecules composed of at least 2 or more fused benzene rings that share two common carbon atoms and they solely consist of carbon and hydrogen [16-19]. Polycyclic aromatic hydrocarbon molecules originate from two standard sources-natural and anthropogenic sources. Natural sources of PAH compounds are mainly forest and bush fires, while domestic and industrial combustion processes and exhaust gases from all types of combustion engines are considered anthropogenic sources [20].

Due to its cancerogenic properties, the European Commission (EU) has adopted Commission Regulation (EC) No 835/2011, defining the maximum levels of benzo[a]pyrene and few other polycyclic aromatic carbohydrates classified in the PAH4 group (benzo[a]anthracene-BaA, chrysene-Chry, benzo[b]fluoranthene-BbF and benzo[a]pyrene- $\mathrm{BaP}$ ) which can be found in meat and meat products. Maximum levels of $\mathrm{BaP}$ is $2 \mu \mathrm{g} \mathrm{kg}^{-1}$ and the sum of PAH4 is $12 \mu \mathrm{g} \mathrm{kg}^{-1}$. Despite the application of good manufacturing practice, some countries including Croatia were unable to produce traditional meat products according to these criteria and therefore a new regulation was adopted. In the new Commission Regulation (EC) No 1327/2014, maximum amount of BaP is $5 \mu \mathrm{gg} \mathrm{kg}^{-1}$ and $30 \mu \mathrm{g} \mathrm{kg}^{-1}$ for PAH4. In this research paper, 16 PAHs (PAH16 - naphthaleneNap, acenaphthylene-Anl, acenaphthene-Ane, fluorene-Flu, phenanthrene-Phen, anthracene-Ant, fluoranthene-Flt, pyrene-Pyr, benz[a]anthracene-BaA, chryseneChry, benzo[b]fluoranthene-BbF, benzo[k]fluoranthene-BkF, benzo[a]pyrene-BaP, indeno[1,2,3-cd]pyrene-InP, dibenz[a,h]anthracene-DahA and benzo[g,h,i]peryleneBghiP), defined by the U.S. Environmental Protection Agency (EPA), were analyzed [11-13,21-23].

The subject of this study was traditional dry-cured and smoked products and its aim was to determine and quantify the types and concentrations of 16 PAHs in the selected samples of Slavonska slanina.

\section{Materials and Methods}

\subsection{Sample Preparation and Smoking}

Fresh pork bellies (weighing cca. $8 \mathrm{~kg}$ ) were purchased at a local market (from local producers). After the removal of rib bones, the samples were trimmed in a traditional manner. In traditional smoking, pre-prepared and chilled pork bellies are first dry-salted for 21 days and then washed in order to remove the excess salt. Smoke is produced by burning hard woods-hornbeam, beech and beech sawdust. Smoking was carried out every other day, for 3-4 h, for a total of 12 days. This means that the bacon was exposed to smoke for a total of 6 times. The samples were in direct contact with the open fire. The mass ratio of wood and sawdust used was approximately 50:50. In industrial smoking, only sawdust in the same proportions was used.

Temperature and humidity were not controlled - they varied depending on natural climate conditions. The temperature varied between 2.1 and $12.2{ }^{\circ} \mathrm{C}\left(\right.$ average temperature $=8.1{ }^{\circ} \mathrm{C}$ ) and the relative humidity from 63.1 to $95.7 \%$ (average humidity was $86.3 \%$ ). 
Industrial smoking was carried out in an industrial smokehouse (Maurer-Atmos Middleby $\mathrm{GmbH}$, Reichenau, Germany), where smoke was produced using a smoke generator with a heated plate using beech sawdust. This resulted in smoke at the temperature of about $25^{\circ} \mathrm{C}$ being transported to the chamber, indicating indirect smoking.

Temperature and relative humidity were controlled throughout the production process. The average temperature was $11.7{ }^{\circ} \mathrm{C}$ and the average relative humidity was $81.4 \%$. Smoking lasted for 4 days and during this period the bacon was smoked for $12 \mathrm{~h}(4 \times 180 \mathrm{~min})$.

Both smoking procedures are performed in three batches. Sampling was performed after the smoking procedure (3 samples), as shown in Figure 1. All samples collected for PAH determination were homogenized and stored in stopper glass bottles, previously washed with acetone, in a dark place at $-30{ }^{\circ} \mathrm{C}$. All the analyses were performed in 3 parallels.

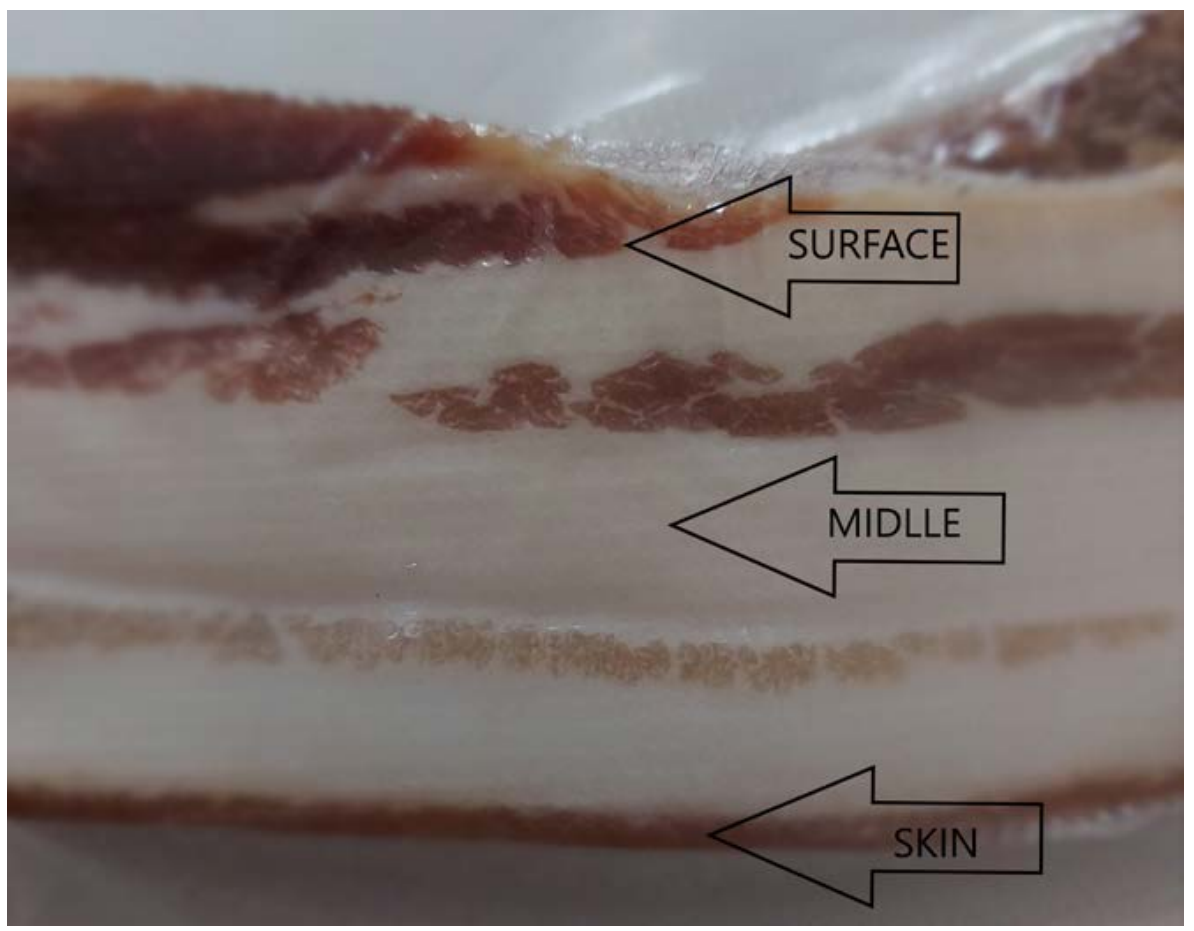

Figure 1. Dry cured smoked bacon Slavonska slanina (cross section) with sampling positions for PAH determination.

\subsection{Determination of Physical-Chemical Properties}

Determination of the basic chemical composition (meat proteins, fat, moisture, collagen) of bacon before and after smoking was performed on a Foss Food Scan Meat Analyzer based on the official AOAC method 2007.04. [24]

In addition to the chemical composition, the $\mathrm{pH}$ value in fresh bacon, bacon after processing but before smoking and bacon after smoking in industrial and traditional conditions was determined. The $\mathrm{pH}$ value was determined with a $\mathrm{pH} / \mathrm{Ion}$-Bench $\mathrm{pH} / \mathrm{Ion} / \mathrm{mV}$ meter manufactured by Eutech Instruments Pte Ltd. (Paisley, UK). The measurement was performed in accordance with the ISO 2917: 1999 standard (HRN ISO 2917, 2000) and according to the instructions of the $\mathrm{pH}$ meter manufacturer.

Water activity $\left(a_{\mathrm{w}}\right)$ was determined using a HygroLab 3-Multi-channel Humidity and Water Activity Analyzer (Rotronic, Switzerland), at room temperature of $20{ }^{\circ} \mathrm{C}$ with a maximum temperature deviation of $\pm 2{ }^{\circ} \mathrm{C}$.

Texture profile analysis (TPA) tests were performed using a TA.XT2i SMS Stable Micro Systems Texture Analyzer (Stable Microsystems Ltd., Surrey, UK) equipped with a compression plate $\mathrm{P} / 75$. The samples were cut in cubes with dimensions of $1.5 \mathrm{~cm} \times 1.5 \mathrm{~cm} \times 1.5 \mathrm{~cm}$. The cubes were compressed twice to $60 \%$. During the test the curves were recorded (force- 
time) at a recording speed of $5 \mathrm{~mm} \mathrm{~s}^{-1}$. Hardness $(\mathrm{kg})$, springiness $(\mathrm{mm})$, cohesiveness, and chewiness $(\mathrm{kg} \cdot \mathrm{mm})$ as a texture profile analysis parameter were determined according to Bourne et al. 1978 [25]:

Hunter-Lab Mini ScanXE (A60-1010-615 Model Colorimeter, Hunter-Lab, Reston, VA, USA) was used for determination of $\mathrm{L}^{*}, \mathrm{a}^{*}$, and $\mathrm{b}^{*}$ values (instrumental color parameters) The instrument was standardized each time with a white and black ceramic plate $\left(L^{*} 0=93.01, a^{*} 0=-1.11\right.$, and $\left.b^{*} 0=1.30\right)$. The $L^{*}$, values represent lightness, $a^{*}$ represent greenness $\left(-a^{*}\right)$ or redness $\left(+a^{*}\right)$, and $b^{*}$ blueness $\left(-b^{*}\right)$ or yellowness $\left(+b^{*}\right)$. Three determinations for general composition, $\mathrm{pH}$ and $a_{\mathrm{w}}$ and eight for texture and color parameters were measured from each sample.

\subsection{Procedure for Determination of PAHs Using the GC-MS Method}

The procedure for the determination of PAHs was performed as described by Petrović et al. (2019) [26] with $4 \mu \mathrm{L}$ of the prepared sample, which was injected into a capillary column of molten silicon dioxide HP-5 MS with the length of $30 \mathrm{~m}$, an inner diameter of $0.25 \mathrm{~mm}$ and a layer thickness of $0.25 \mu \mathrm{m}$ at the temperature of $280{ }^{\circ} \mathrm{C}$ and a constant pressure of 11.36 psi., a constant carrier gas flow of $1.2 \mathrm{~mL} \mathrm{~min}^{-1}$. Column temperature program was the following:

- $\quad$ Initial temperature $50{ }^{\circ} \mathrm{C}$ for $24 \mathrm{~s}$;

- Gradient $25^{\circ} \mathrm{C} \min ^{-1}$ from initial temperature $\left(50{ }^{\circ} \mathrm{C}\right)$ to $195^{\circ} \mathrm{C}$ for $90 \mathrm{~s}$;

- $\quad$ Gradient $8{ }^{\circ} \mathrm{C} \min ^{-1}$ from $195^{\circ} \mathrm{C}$ to $265^{\circ} \mathrm{C}$;

- $\quad$ Maintenance at $315^{\circ} \mathrm{C}$ for $75 \mathrm{~s}$ with $20^{\circ} \mathrm{C} \min ^{-1}$.

The temperature of the detector was $280^{\circ} \mathrm{C}$, and the analysis itself was performed in 3 samples. Determination of the obtained values (represented by peaks) was done on the basis of retention time and target ions, by the method of external standard and using a standard solution. The control sample (or blank) and the solvents used in the analysis were analyzed and no PAH compounds were found in them.

Due to the lipophilicity of the PAH compounds, olive oil was chosen as the matrix on which the method was validated. Olive oil was also subjected to analysis and it was found to be free from PAH residues that are the subject of the test. The validation of the method was carried out in accordance with Commission Regulation (EC) No 333/2007 and Commission Regulation (EC) No 836/2011.

The linearity of the detectors was tested in the range of 5 to $500 \mathrm{mg} \mathrm{kg}^{-1}$, while the accuracy of the method was assessed by repeatability, using olive oil enriched with concentrations of PAHs injected in three copies $\left(50.0 \mu \mathrm{g} \mathrm{kg}^{-1}, n=20\right)$.

\subsection{Statistical Analysis}

The data obtained by the experiment were subjected to the analysis of variance (ANOVA) and Fisher's least significant difference (LSD) tests, with significance defined at $p<0.05$. Statistical analysis was carried out using Statistica 12.7 (2015, StatSoft Inc., Tulsa, OK, USA).

\section{Results and Discussion}

\subsection{Physico-Chemical Properties}

The basic chemical composition of fresh pork belly was the following: the average protein content was $17.75 \%$ (S. D. $=0.38)$, the fat content $21.47 \%$ (S. D. $=0.25)$, the collagen content with a mean value of $2.16 \%($ S. D. $=0.15)$, and the moisture content $60.38 \%$ $(\mathrm{S} . \mathrm{D} .=0.41)$. Physical properties which were analyzed in this paper were $\mathrm{pH}$ having a constant value of 5.59 (S. D. $=0.12$ ) and water activity with the value of 0.98 (S. D. $=0.10$ ).

The physico-chemical properties of Slavonska slanina after smoking are shown in Table 1. In contrast to raw pork samples, at the end of traditional smoking process, the average value of protein content was $21.09 \%$, fat $35.74 \%$, collagen $2.16 \%$ and moisture was $39.57 \%$. Water activity averaged at 0.92 , while $\mathrm{pH}$ was the same as in raw material with the 
value of 5.59 (Table 1). In the samples subjected to industrial smoking, the average protein content was $22.18 \%$, fat $33.09 \%$, moisture $40.74 \%$, collagen $1.83 \%$, while water activity was 0.92 and $\mathrm{pH}$ averaged at 5.58 (Table 1). When determining the color, a statistically significant $(p<0.05)$ difference was observed depending on the type of smoking (Table 1 ), so the $\mathrm{L}^{*}$ value in traditional smoking averaged at 62.37 , while in industrial smoking it was 61.88 . The average value of parameter $\mathrm{a}^{*}$ in traditional smoking was 8.17 , and in industrial smoking it amounted 8.82, while the average value of parameter $b^{*}$ was 17.80 for traditional smoking and 17.07 for industrial smoking. Similarly, higher values for redness $\left(\mathrm{a}^{*}\right)$ of Petrovska klobasa samples smoked in industrial conditions were recorded compared to the samples smoked in traditional manner reported by Škaljac et al. 2018 [27]. Moreover, João Fraqueza et al. 2020 [28] reported higher values for L* and lower values for a* for Portuguese sausage that was smoked for a longer period of time.

Table 1. Physico-chemical properties of Slavonska slanina.

\begin{tabular}{ccc}
\hline & Traditional Smoking & Industrial Smoking \\
\hline Protein [\%] & $21.09^{\mathrm{b}} \pm 0.04$ & $22.18^{\mathrm{a}} \pm 0.02$ \\
Fat [\%] & $35.74^{\mathrm{a}} \pm 0.02$ & $33.09^{\mathrm{b}} \pm 0.05$ \\
Moisture [\%] & $39.57^{\mathrm{b}} \pm 0.05$ & $40.74^{\mathrm{a}} \pm 0.01$ \\
Collagen [\%] & $2.16^{\mathrm{a}} \pm 0.02$ & $1.83^{\mathrm{b}} \pm 0.04$ \\
$\mathrm{pH}$ & $5.59^{\mathrm{a}} \pm 0.02$ & $5.58^{\mathrm{a}} \pm 0.01$ \\
$a_{\mathrm{w}}$ & $0.92^{\mathrm{a}} \pm 0.01$ & $0.92^{\mathrm{a}} \pm 0.01$ \\
$\mathrm{~L}^{*}$ & $62.37^{\mathrm{a}} \pm 0.49$ & $61.88^{\mathrm{a}} \pm 1.56$ \\
$\mathrm{a}^{*}$ & $8.17^{\mathrm{b}} \pm 0.19$ & $8.82^{\mathrm{a}} \pm 0.26$ \\
$\mathrm{~b}^{*}$ & $17.80^{\mathrm{a}} \pm 0.21$ & $17.07^{\mathrm{b}} \pm 0.27$ \\
Hardness (kg) & $7.91^{\mathrm{a}} \pm 0.10$ & $5.81^{\mathrm{b}} \pm 0.35$ \\
Springiness (mm) & $0.57^{\mathrm{a}} \pm 0.09$ & $0.74^{\mathrm{a}} \pm 0.03$ \\
Cohesiveness & $0.58^{\mathrm{b}} \pm 0.04$ & $0.71^{\mathrm{a}} \pm 0.02$ \\
Chewiness $(\mathrm{kg} \cdot \mathrm{mm})$ & $2.61^{\mathrm{a}} \pm 0.11$ & $3.05^{\mathrm{a}} \pm 0.32$ \\
\hline
\end{tabular}

$\overline{\mathrm{a}, \mathrm{b}}$ Means ( \pm standard deviation) within rows with different superscripts are significantly different $(p<0.05)$

The values obtained by the analysis of the texture profile (Table 1 ) show that the greatest statistically significant $(p<0.05)$ differences occurred in the hardness parameterthe average value in industrial smoking was $5.81 \mathrm{~kg}$, while in traditional smoking it was $7.91 \mathrm{~kg}$. Such results are expected because in industrial smoking the conditions are controlled and the result is a product with uniform properties, which is probably due to a longer smoking time in the traditional procedure [28].

The mean value of springiness in industrial smoking was 0.74 , while in traditional smoking it was 0.57 . The mean value of cohesiveness in industrial smoking was 0.71 in contrast to the traditional method of smoking in which this value was 0.58 , which showed statistically significant difference $(p<0.05)$. The compared mean values for chewing resistance were $3.05 \mathrm{~kg}$ for industrial smoking and $2.61 \mathrm{~kg}$ for traditional smoking.

\subsection{PAH Determination}

Only light PAHs (Nap, Anl and Ane) were found in the raw pig bellies and their concentrations were below the limit of quantification.

This research in traditional dry-cured and smoked bacon has determined the presence of 11 of the 16 analyzed polycyclic aromatic hydrocarbons (Nap, Anl, Ane, Fln, Ant, Phen, Flt, BaA, Pyr, BbF, BkF), which are on the EPA list [29] for traditional smoking, and only two (Nap, Anl) for industrial smoking (Table 2). European Regulation No 1327/2014, which is directly applicable in the Republic of Croatia for traditionally produced meat products, prescribes a maximum concentration of benzo(a)pyrene of $5 \mu \mathrm{g} \mathrm{kg}^{-1}$ and a PAH4 content of a maximum of $30 \mu \mathrm{g} \mathrm{kg}-1$. 
Table 2. PAH contents $\left(\mu \mathrm{g} \mathrm{kg}^{-1}\right)$ in Slavonska slanina.

\begin{tabular}{|c|c|c|c|c|c|c|}
\hline РАH & $\begin{array}{c}\text { Traditional } \\
\text { Smoking- } \\
\text { Middle }\end{array}$ & $\begin{array}{c}\text { Traditional } \\
\text { Smoking- } \\
\text { Surface }\end{array}$ & $\begin{array}{c}\text { Traditional } \\
\text { Smoking-Skin }\end{array}$ & $\begin{array}{c}\text { Industrial } \\
\text { Smoking- } \\
\text { Middle }\end{array}$ & $\begin{array}{c}\text { Industrial } \\
\text { Smoking- } \\
\text { Surface }\end{array}$ & $\begin{array}{c}\text { Industrial } \\
\text { Smoking- } \\
\text { Skin }\end{array}$ \\
\hline Nap & $157.75^{\mathrm{a}} \pm 0.92$ & $79.00^{\mathrm{a}, \mathrm{b}} \pm 0.75$ & $27.46^{b} \pm 0.64$ & $64.20^{b} \pm 0.56$ & $21.62^{b} \pm 0.64$ & $18.62^{b} \pm 0.35$ \\
\hline Anl & $325.00^{\mathrm{a}} \pm 1.71$ & $179.62^{\mathrm{a}} \pm 0.97$ & $179.76^{\mathrm{a}} \pm 1.02$ & $16.28^{b} \pm 0.65$ & $<$ LOQ & $<\mathrm{LOQ}$ \\
\hline Ane & $4.79^{\mathrm{a}} \pm 0.70$ & $<$ LOQ & $<$ LOQ & $<\mathrm{LOQ}$ & $<\mathrm{LOQ}$ & $<\mathrm{LOQ}$ \\
\hline Fln & $157.62^{\mathrm{a}} \pm 1.62$ & $86.76^{a} \pm 0.69$ & $142.53^{\mathrm{a}} \pm 0.71$ & $<\mathrm{LOQ}$ & $<\mathrm{LOQ}$ & $<\mathrm{LOQ}$ \\
\hline Ant & $102.31^{\mathrm{a}} \pm 1.13$ & $48.19^{a} \pm 0.48$ & $119.20^{a} \pm 0.77$ & $<\mathrm{LOQ}$ & $<\mathrm{LOQ}$ & $<\mathrm{LOQ}$ \\
\hline Phen & $432.88^{a} \pm 3.11$ & $210.38^{a} \pm 0.78$ & $504.17^{\mathrm{a}} \pm 1.69$ & $<\mathrm{LOQ}$ & $<\mathrm{LOQ}$ & $<\mathrm{LOQ}$ \\
\hline Flt & $42.23^{a} \pm 0.85$ & $20.49^{a} \pm 0.56$ & $50.37^{a} \pm 0.56$ & $<\mathrm{LOQ}$ & $<\mathrm{LOQ}$ & $<\mathrm{LOQ}$ \\
\hline $\mathrm{BaA}$ & $13.59^{\mathrm{a}} \pm 0.33$ & $9.72^{\mathrm{a}} \pm 0.63$ & $16.53^{\mathrm{a}} \pm 0.84$ & $<\mathrm{LOQ}$ & $<\mathrm{LOQ}$ & $<\mathrm{LOQ}$ \\
\hline Pyr & $53.15^{\mathrm{a}} \pm 0.64$ & $37.34^{a} \pm 0.77$ & $31.97^{\mathrm{a}} \pm 0.88$ & $<\mathrm{LOQ}$ & $<\mathrm{LOQ}$ & $<$ LOQ \\
\hline Chry & $<\mathrm{LOQ}$ & $<\mathrm{LOQ}$ & $<\mathrm{LOQ}$ & $<\mathrm{LOQ}$ & $<\mathrm{LOQ}$ & $<\mathrm{LOQ}$ \\
\hline $\mathrm{BbF}$ & $1.25^{\mathrm{a}} \pm 0.10$ & $0.89^{a} \pm 0.06$ & $0.84^{\mathrm{a}} \pm 0.11$ & $<\mathrm{LOQ}$ & $<\mathrm{LOQ}$ & $<\mathrm{LOQ}$ \\
\hline $\mathrm{BkF}$ & $3.84^{\mathrm{a}} \pm 0.08$ & $3.65^{\mathrm{a}} \pm 0.10$ & $3.69^{a} \pm 0.14$ & $<\mathrm{LOQ}$ & $<\mathrm{LOQ}$ & $<\mathrm{LOQ}$ \\
\hline $\mathrm{BaP}$ & $<\mathrm{LOQ}$ & $<\mathrm{LOQ}$ & $<\mathrm{LOQ}$ & $<\mathrm{LOQ}$ & $<\mathrm{LOQ}$ & $<\mathrm{LOQ}$ \\
\hline DahA & $<\mathrm{LOQ}$ & $<\mathrm{LOQ}$ & $<\mathrm{LOQ}$ & $<\mathrm{LOQ}$ & $<\mathrm{LOQ}$ & $<\mathrm{LOQ}$ \\
\hline BghiP & $<\mathrm{LOQ}$ & $<\mathrm{LOQ}$ & $<\mathrm{LOQ}$ & $<\mathrm{LOQ}$ & $<\mathrm{LOQ}$ & $<\mathrm{LOQ}$ \\
\hline InP & $<\mathrm{LOQ}$ & $<\mathrm{LOQ}$ & $<\mathrm{LOQ}$ & $<\mathrm{LOQ}$ & $<\mathrm{LOQ}$ & $<\mathrm{LOQ}$ \\
\hline ¿PAH4 & $14.84^{\mathrm{a}} \pm 0.25$ & $10.61^{\mathrm{a}} \pm 0.69$ & $17.37^{\mathrm{a}} \pm 0.74$ & $<\mathrm{LOQ}$ & $<\mathrm{LOQ}$ & $<\mathrm{LOQ}$ \\
\hline$\sum \mathrm{PAH} 16$ & $1294.41^{\mathrm{a}} \pm 4.65$ & $676.04^{a} \pm 1.33$ & $1076.52^{a} \pm 5.90$ & $80.48^{b} \pm 0.89$ & $21.62^{b} \pm 0.63$ & $18.62^{b} \pm 0.35$ \\
\hline
\end{tabular}

The analysis of PAH content included measuring their content on the surface (the fleshy side), in the middle and in the skin of the bacon. The analysis of PAH4 content in traditional dried and smoked bacon smoked in the traditional way revealed the presence of BaA (13.59 $\mathrm{\mu g} \mathrm{kg}^{-1}$ in the middle, $9.72 \mu \mathrm{g} \mathrm{kg}{ }^{-1}$ on the surface and $16.53 \mu \mathrm{g} \mathrm{kg}^{-1}$ in the skin) and $\operatorname{BbF}\left(1.25 \mu \mathrm{g} \mathrm{kg}^{-1}\right.$ in the middle, $0.89 \mu \mathrm{g} \mathrm{kg}^{-1}$ on the surface and $0.84 \mu \mathrm{g} \mathrm{kg}^{-1}$ in the skin), while Chry and BaP concentrations were below the level of quantification $(<\mathrm{LOQ})$. Relative high values of $\mathrm{BaA}$ as and $\mathrm{BbF}$ in the middle of the samples may be related to the PAH lipophilic nature [30], since they probably migrate from the surface to the middle part of the product (bacon has a higher fat content in the middle).

The total value of PAH4 when the traditional smoking method is applied amounted to $14.84 \mu \mathrm{g} \mathrm{kg}^{-1}$ in the middle, $10.61 \mu \mathrm{g} \mathrm{kg}{ }^{-1}$ on the surface and $17.37 \mu \mathrm{g} \mathrm{kg}^{-1}$ in the skin of bacon. Similarly, lower values of PAH4 when industrial smoking of dry sausage is applied were reported by Škrbić et al., 2014 [31]. Other studies on similar samples reveled lower PAH4 values for samples smoked in controlled conditions [12,32,33]. In contrast to the research conducted by Mastanjević et al. (2020) on traditionally smoked ham (Slavonska šnk $\mathrm{ka})$, where PAH4 values were elevated in four samples $\left(>30 \mu \mathrm{g} \mathrm{kg}^{-1}\right)$, this analysis did not find a non-compliance of domestic smoked bacon samples with the European Regulation EC No 1327/2014. In bacon smoked in industrial conditions, the concentration of PAH4 was below the quantification level (<LOQ).

The PAH16 content in the analyzed samples is presented in Table 2. The highest PAH 16 concertation was determined in the middle part of traditionally smoked samples. On the other hand, Puljić et al., 2019 [34] reported lower values in the inner parts of dry cured and smoked pig loin Hercegovačka pečenica, which can be caused by the smoking method and the relatively high fat content in Slavonska slanina. Such results are expected because of the PAH lipophilic character $[35,36]$. Other studies on dry smoked sausages showed a lower PAH content in the middle of the product [37-39], which can be related to the fact that sausages have casings (barrier between smoke and the meat product). PAH16 content in the middle of the bacon was $1294.41 \mu \mathrm{g} \mathrm{kg}^{-1}, 676.04 \mu \mathrm{g} \mathrm{kg}^{-1}$ on the surface and $1076.52 \mu \mathrm{g} \mathrm{kg}^{-1}$ in the skin when it was smoked in the traditional way. In the industrial 
smoking of traditional dry-cured and smoked bacon, the PAH16 content was $80.48 \mu \mathrm{gg}^{-1}$ in the middle, $21.62 \mu \mathrm{g} \mathrm{kg}^{-1}$ on the surface and $18.62 \mu \mathrm{g} \mathrm{kg}^{-1}$ in the skin of the bacon [24].

\section{Conclusions}

This investigation showed that traditional smoking of Slavonska slanina may result in formation of some potentially cancerogenic $\mathrm{BaA}$ and $\mathrm{BbF}$ (especially in the middle of the product which is actually consumed). However, the concentrations were below the currently prescribed $30 \mu \mathrm{g} \mathrm{kg}^{-1}$. The concentrations up to $30 \mu \mathrm{g} \mathrm{kg}^{-1}$ of PAH4 are allowed and defined by the derogation of the Commission Regulation (EC) No 835/2011 and are applicable only to the traditional meat products. If the Commission Regulation (EC) No $835 / 2011$ was in force, the samples of Slavonska slanina would have the concentrations of PAH4 above the prescribed level/OR the concentrations would be higher than allowed. The traditional smoking method can be used, but more controlled conditions must be in force (time of smoking and the wood temperature combustion). The industrially smoked samples had <LOQ concentrations of PAH4 and BaP. Different smoking procedures affected protein, fat and moisture content, color parameters $\left(a^{*}\right.$ and $b^{*}$ ) and texture parameters (hardness and cohesiveness) of Slavonska slanina, which may be related to a longer smoking time for traditionally smoked samples.

Author Contributions: Conceptualization, K.M. methodology, B.K.; software, K.M.; validation, B.K., J.V.; investigation, L.P., D.K.; data curation, K.H., D.K.; writing-original draft preparation, K.M., M.M., writing-review and editing, K.H.; supervision, K.M. All authors have read and agreed to the published version of the manuscript.

Funding: This research received no external funding.

Institutional Review Board Statement: Not applicable.

Informed Consent Statement: Not applicable.

Conflicts of Interest: The authors declare no conflict of interest.

\section{References}

1. Kovačević, D. Kemija i Tehnologija Mesa i Ribe; Prehrambeno Tehnološki Fakultet: Osijek, Croatia, 2001.

2. Krvavica, M.; Đugum, J. Proizvodnja pršuta u svijetu i kod nas. MESO Prvi Hrvatski Časopis Mesu 2006, 8, 355-365. Available online: https:/ / hrcak.srce.hr/22460 (accessed on 13 December 2021).

3. Andrée, S.; Jira, W.; Schwind, K.-H.; Wagner, H.; Schwägele, F. Chemical Safety of Meat and Meat Products. Meat Sci. 2010, 86, 38-48. [CrossRef] [PubMed]

4. Regulation (EU) No. 1151/2012 of the European Parliament and of the Council on Quality Schemes for Agricultural Products and Foodstuffs. Available online: https:/ / www.ecolex.org/details/legislation/regulation-eu-no-11512012-of-the-europeanparliament-and-of-the-council-on-quality-schemes-for-agricultural-products-and-foodstuffs-lex-faoc118307/ (accessed on 13 December 2021).

5. Gómez, I.; Janardhanan, R.; Ibañez, F.C.; Beriain, M.J. The Effects of Processing and Preservation Technologies on Meat Quality: Sensory and Nutritional Aspects. Foods 2020, 9, 1416. [CrossRef] [PubMed]

6. Sander, L.C.; Wise, S.A. Polycyclic Aromatic Hydrocarbon Structure Index; US Department of Commerce, Technology Administration, National Institute of Gaithersburg: Gaithersburg, MD, USA, 1997.

7. Martorell, I.; Perello, G.; Marti-Cid, R.; Castell, V.; Llobet, J.M.; Domingo, J.L. Polycyclic Aromatic Hydrocarbons (PAH) in Foods and Estimated PAH Intake by the Population of Catalonia, Spain: Temporal Trend. Environ. Int. 2010, 36, 424-432. [CrossRef] [PubMed]

8. Rozentale, I.; Zacs, D.; Bartkiene, E.; Bartkevics, V. Polycyclic Aromatic Hydrocarbons in Traditionally Smoked Meat Products from the Baltic States. Food Addit. Contam. Part B-Surveill. 2018, 11, 138-145. [CrossRef]

9. Ciecierska, M.; Obiedzinski, M. Influence of Smoking Process on Polycyclic Aromatic Hydrocarbons' Content in Meat Products. Acta Sci. Polon.-Technol. Aliment. 2007, 6, 17-28.

10. Roseiro, L.C.; Gomes, A.; Patarata, L.; Santos, C. Comparative Survey of PAHs Incidence in Portuguese Traditional Meat and Blood Sausages. Food Chem. Toxicol. 2012, 50, 1891-1896. [CrossRef]

11. Santos, C.; Gomes, A.; Roseiro, L.C. Polycyclic Aromatic Hydrocarbons Incidence in Portuguese Traditional Smoked Meat Products. Food Chem. Toxicol. 2011, 49, 2343-2347. [CrossRef] 
12. Skaljac, S.; Petrovic, L.; Tasic, T.; Ikonic, P.; Jokanovic, M.; Tomovic, V.; Dzinic, N.; Sojic, B.; Tjapkin, A.; Skrbic, B. Influence of Smoking in Traditional and Industrial Conditions on Polycyclic Aromatic Hydrocarbons Content in Dry Fermented Sausages (Petrovska Klobasa) from Serbia. Food Control 2014, 40, 12-18. [CrossRef]

13. Mastanjević, K.; Puljić, L.; Kartalović, B.; Grbavac, J.; Jukić Grbavac, M.; Nadaždi, H.; Habschied, K. Analysis of Polycyclic Aromatic Hydrocarbons in Heregovački Pršut—Traditionally Smoked Prosciutto. Int. J. Environ. Res. Public Health 2020, $17,5097$. [CrossRef]

14. Mastanjević, K.M.; Kartalović, B.D.; Vranešević, J.M.; Novakov, N.J.; Habschied, K.J. Polycyclic Aromatic Hydrocarbons in Traditionally Smoked Slavonska Kobasica. Food Addit. Contam. Part B 2020, 13, 82-87. [CrossRef] [PubMed]

15. Ziegenhals, K.; Mueller, W.-D.; Jira, W.; Speer, K. Lower contents of PAH by optimized smoking terms. Fleischwirtschaft 2008, 88, 93-97.

16. Purcaro, G.; Moret, S.; Conte, L.S. Optimisation of Microwave Assisted Extraction (MAE) for Polycyclic Aromatic Hydrocarbon (PAH) Determination in Smoked Meat. Meat Sci. 2009, 81, 275-280. [CrossRef] [PubMed]

17. Mastanjevic, K.; Kartalovic, B.; Petrovic, J.; Novakov, N.; Puljic, L.; Kovacevic, D.; Jukic, M.; Lukinac, J.; Mastanjevic, K. Polycyclic Aromatic Hydrocarbons in the Traditional Smoked Sausage Slavonska Kobasica. J. Food Compos. Anal. 2019, 83, 103282. [CrossRef]

18. Wade, L.G. Organic Chemistry; Pearson Prentice Hall: Upper Saddle River, NJ, USA, 2006; ISBN 978-0-13-147871-8.

19. Simko, P. Factors Affecting Elimination of Polycyclic Aromatic Hydrocarbons from Smoked Meat Foods and Liquid Smoke Flavorings. Mol. Nutr. Food Res. 2005, 49, 637-647. [CrossRef]

20. Wenzl, T.; Zelinkova, Z. Polycyclic Aromatic Hydrocarbons in Food and Feed. In Encyclopedia of Food Chemistry; Melton, L., Shahidi, F., Varelis, P., Eds.; Academic Press: Oxford, UK, 2019; pp. 455-469. ISBN 978-0-12-814045-1.

21. Commission Regulation (EC). No 1881/2006 of 19 December 2006. Setting Maximum Levels for Certain Contaminants in Foodstuffs (Text with EEA Relevance). Off. J. Eur. Union 2006, 364, 5-24.

22. Zelinkova, Z.; Wenzl, T. The Occurrence of 16 EPA PAHs in Food-A Review. Polycycl. Aromat. Compd. 2015, 35, 248-284. [CrossRef]

23. Commission Regulation (EU). No 1327/2014 of 12 December 2014. Amending Regulation (EC). No 1881/2006 as Regards Maximum Levels of Polycyclic Aromatic Hydrocarbons (PAHs) in Traditionally Smoked Meat and Meat Products and Traditionally Smoked Fish and Fishery Products Text with EEA Relevance. Off. J. Eur. Union 2014, 358, 13-14.

24. Official Methods of Analysis of AOAC Internationa, 17th ed.; Association of Official Analytical Chemists, Inc.: Arlington, VA, USA, 2021.

25. Bourne, M.C.; Kenny, J.F.; Barnard, J. Computer-Assisted Readout of Data from Texture Profile Analysis Curves1. J. Texture Stud. 1978, 9, 481-494. [CrossRef]

26. Petrović, J.; Kartalović, B.; Ratajac, R.; Spirić, D.; Djurdjević, B.; Polaček, V.; Pucarević, M. PAHs in Different Honeys from Serbia. Food Addit. Contam. Part B 2019, 12, 116-123. [CrossRef]

27. Skaljac, S.; Jokanovic, M.; Tomovic, V.; Ivic, M.; Tasic, T.; Ikonic, P.; Sojic, B.; Dzinic, N.; Petrovic, L. Influence of Smoking in Traditional and Industrial Conditions on Colour and Content of Polycyclic Aromatic Hydrocarbons in Dry Fermented Sausage "Petrovska Klobasa". LWT-Food Sci. Technol. 2018, 87, 158-162. [CrossRef]

28. Fraqueza, M.J.; Laranjo, M.; Alves, S.; Fernandes, M.H.; Agulheiro-Santos, A.C.; Fernandes, M.J.; Potes, M.E.; Elias, M. Dry-Cured Meat Products According to the Smoking Regime: Process Optimization to Control Polycyclic Aromatic Hydrocarbons. Foods 2020, 9, 91. [CrossRef] [PubMed]

29. US EPA National Center for Environmental Assessment, I.O.; Murphy, P. EPA's Report on the Environment (ROE) (2008 Final Report). Available online: https:// cfpub.epa.gov/ncea/risk/recordisplay.cfm?deid=190806 (accessed on 30 October 2021).

30. Kamankesh, M.; Mohammadi, A.; Hosseini, H.; Modarres Tehrani, Z. Rapid Determination of Polycyclic Aromatic Hydrocarbons in Grilled Meat Using Microwave-Assisted Extraction and Dispersive Liquid-Liquid Microextraction Coupled to Gas Chromatography-Mass Spectrometry. Meat Sci. 2015, 103, 61-67. [CrossRef]

31. Skrbic, B.; Durisic-Mladenovic, N.; Macvanin, N.; Tjapkin, A.; Skaljac, S. Polycyclic Aromatic Hydrocarbons In Smoked Dry Fermented Sausages with Protected Designation Of Origin Petrovska Klobasa From Serbia. Maced. J. Chem. Chem. Eng. 2014, 33, 227-236. [CrossRef]

32. Ledesma, E.; Rendueles, M.; Diaz, M. Benzo(a)Pyrene Penetration on a Smoked Meat Product during Smoking Time. Food Addit. Contam. Part A-Chem. 2014, 31, 1688-1698. [CrossRef]

33. Babic, J.M.; Kartalovic, B.D.; Skaljac, S.; Vidakovic, S.; Ljubojevic, D.; Petrovic, J.M.; Cirkovic, M.A.; Teodorovic, V. Reduction of Polycyclic Aromatic Hydrocarbons in Common Carp Meat Smoked in Traditional Conditions. Food Addit. Contam. Part B-Surveill. 2018, 11, 208-213. [CrossRef]

34. Puljić, L.; Mastanjević, K.; Kartalović, B.; Kovačević, D.; Vranešević, J.; Mastanjević, K. The Influence of Different Smoking Procedures on the Content of 16 PAHs in Traditional Dry Cured Smoked Meat "Hercegovačka Pečenica". Foods 2019, 8, 690. [CrossRef]

35. Olatunji, O.S.; Fatoki, O.S.; Opeolu, B.O.; Ximba, B.J. Determination of Polycyclic Aromatic Hydrocarbons [PAHs] in Processed Meat Products Using Gas Chromatography_Flame Ionization Detector. Food Chem. 2014, 156, 296-300. [CrossRef]

36. Reinik, M.; Tamme, T.; Roasto, M.; Juhkam, K.; Tenno, T.; Kiis, A. Polycyclic Aromatic Hydrocarbons (PAHs) in Meat Products and Estimated PAH Intake by Children and the General Population in Estonia. Food Addit. Contam. 2007, 24, 429-437. [CrossRef] 
37. Mastanjević, K.; Kartalović, B.; Puljić, L.; Kovačević, D.; Habschied, K. Influence of Different Smoking Procedures on Polycyclic Aromatic Hydrocarbons Formation in Traditional Dry Sausage Hercegovačka Kobasica. Processes 2020, 8, 918. [CrossRef]

38. Ledesma, E.; Rendueles, M.; Diaz, M. Contamination of Meat Products during Smoking by Polycyclic Aromatic Hydrocarbons: Processes and Prevention. Food Control 2016, 60, 64-87. [CrossRef]

39. Skaljac, S.; Petrovic, L.; Jokanovic, M.; Tasic, T.; Ivic, M.; Tomovic, V.; Ikonic, P.; Sojic, B.; Dzinic, N.; Skrbic, B. Influence of Collagen and Natural Casings on the Polycyclic Aromatic Hydrocarbons in Traditional Dry Fermented Sausage (Petrovska Klobasa) from Serbia. Int. J. Food Prop. 2018, 21, 667-673. [CrossRef] 